\title{
Attitude of Rural Women of Assam towards ICTs
}

\author{
Pompy Malakar* and Manoshi Baruah Deka \\ Department of Extension and Communication Management, College of Home Science, Assam \\ Agricultural University, Jorhat (Assam) India \\ *Corresponding author
}

\begin{abstract}
A B S T R A C T
Information and Communication Technologies include devices, networks, services and applications. These can range from cutting edge Internet-based technologies and sensing tools to other technologies that have been around for much longer. ICTs are very important mainstay that strengthens the extension activities and will carry new information services to rural women. Access to such new information sources is a crucial requirement for the sustainable development of the current farming systems. The present study was conducted to find the attitude of the rural women towards ICTs. Four hundred respondents were selected for final interview of the study. The study showed that majority of the farmers (77\%) have a favourable attitude towards ICTs followed by 14.25 per cent of the respondents have a highly favourable attitude and 8.75 per cent had least favourable attitudes. This means that there is a scope for higher usage of ICTs in disseminating the agriculture related information among the respondents. Similarly significant association had been found between attitude towards ICTs with age, educational qualification, organizational membership and extension contact.
\end{abstract}

Keywords

Rural Women, Information and Communication Technologies (ICT)

Article Info

Accepted: 15 October 2020 Available Online: 10 November 2020

\section{Introduction}

Now-a-days Information Communication Technologies (ICTs) emerge as offering new and updated information's to the rural women directly to their doorstep who are involved in agriculture and allied activities. Information and Communication Technology (ICT) is a combination of both science and technology. It includes cell phone, computer hardware and software, internet, wired and wireless networks, digital still and video cameras etc. In the recent years ICTs have witnessed major changes and are emerging as a powerful tool for transferring agricultural information's among the rural women's. Dhaka and Chayal (2010) focussed their study on the attitude of farmers towards ICT as a source of information and concluded that effective utilization of ICT has potential to make the rural communities prosperous as it enables the dissemination of requisite information in user friendly form, easy to access, cost-effective ways at the right time. Shankaraiah and Swamy (2012) show that in Doddaballapura $32.5 \%$ of the farmers had most favourable attitude while $40 \%$ of farmers had favourable attitude followed by $27.5 \%$ who had least favourable attitude towards MMS network. 
The favourable attitude of rural women towards ICT is very much necessary for obtaining benefit of effective and efficient information communication tools which would build confidence among the rural women to take agriculture and allied related decisions and it will also make extension programme more efficient in changing agrirural environment. Therefore the present study was undertaken to assess the attitude of rural women towards ICTs and to find out the association with socio-economic characteristics of the respondents.

\section{Materials and Methods}

\section{Location of study}

The study was carried out in the state of Assam. Simple random sampling was selected for selection of districts, blocks, villages and respondents. Jorhat and Titabor districts were selected randomly from the state of Assam. From the selected districts four (4) blocks were selected following simple random sampling method, out of the four blocks two (2) villages were selected randomly. Thus altogether eight (8) villages were selected.

\section{Selection of respondents}

Fifty (50) respondents were selected from each village, thus altogether 200 respondents were selected from each district. Thus a total of 400 rural women were finally selected for data collection of the study.

\section{Measurement of variables}

In the present study attitude was selected as the dependent variable and age, sex, education, occupation, land holding, annual income and social participation were selected as the independent variables. The investigator measured the attitude through the scale developed by Kumar and Ratnakar (2011) with slight modification. Eighteen (18) statements were selected and were measured in Likert 5 point continuum scale i.e., 'Strongly Agree', 'Agree', 'Un-decided', 'Disagree', and 'Strongly Disagree' with scores of 5,4,3,2,1 respectively for positive statements and the reverse for negative statements. Mean, standard deviation and chi square test were done using SPSS.

\section{Results and Discussion}

\section{Attitude towards ICTs}

The data in Table 1 reveals that majority of the respondents $(77 \%)$ had a favourable attitude towards ICTs, 14.25 per cent of the respondents had highly favourable attitude and 8.75 per cent had least favourable attitude towards ICTs.

The favourable attitude of the respondents towards ICTs is might be due to their existing knowledge level towards ICTs and also since majority of the respondents were literate and belonged to lower middle age group these might have influenced the respondents to have favourable attitude towards ICTs.

Further the findings implied that there is a scope of more usage of ICTs in disseminating the agriculture and allied related information among the rural women. Since majority of the farmers had favourable attitude towards ICTs therefore, effective utilization of ICT has a potential to make the rural women affluent as it enables the dissemination of requisite information in user friendly form, costeffective and ease to use anywhere, anytime.

\section{Association between selected independent variables with attitudes towards ICTs}

Table 2 shows the association between attitudes with selected independent variables. The finding shows significant association 
between age and attitude. It was found that upper aged respondents had relatively positive attitudes towards ICTs then the younger respondents this may be due to their knowledge on ICTs which formed favourable attitude towards ICTs. Education was also found to have significant association with attitude. This means that with increase with educational qualification respondents had positive attitude towards ICTs as with increase in educational qualification respondents were able to acquire more information which builds positive attitude towards ICTs. Again organizational membership and extension contact had significant association with attitude these means that with regular contact with extension personnel's and membership in different organization leads to favourable attitude towards ICTs.

Table.1 Distribution of respondents according to their attitude towards ICTs N=400

\begin{tabular}{|l|l|l|l|l|l|}
\hline Category & Score range & Frequency & Percentage & Mean & SD \\
\hline Highly favorable & $<3.47$ & 57 & 14.25 & & \\
\hline Favorable & $2.99-3.47$ & 308 & 77.00 & 3.23 & 0.24 \\
\hline Least favorable & $>2.99$ & 35 & 8.75 & & \\
\hline
\end{tabular}

Table.2 Association between selected independent variables with attitude towards ICTs N=400

\begin{tabular}{|l|c|c|}
\hline Variables & Chi-square & Asymp. Sig. (2 tailed) \\
\hline Age & 202.222 & $.000 * *$ \\
\hline Educational qualification & 112.007 & $.000 * *$ \\
\hline Type of family & 121.419 & $.136 \mathrm{NS}$ \\
\hline Size of the family & 178.087 & $.180 \mathrm{NS}$ \\
\hline Organizational membership & 362.000 & $.000 * *$ \\
\hline Extension contact & 64.626 & $.000 * *$ \\
\hline * Significant at 0.01 level probability & & \\
\hline
\end{tabular}

Thus the null hypothesis was rejected at 0.01 level of significant. So it can be concluded that there is significant association between attitude towards ICTs with age, educational qualification, organizational membership and extension contact.

In conclusion the study revealed that majority of the rural women possessed favourable attitude towards ICTs. Hence the study revealed that there is a scope of utilization of ICTs in agriculture and allied areas. The favourable attitude of rural women towards ICT is very much necessary for obtaining benefit of effective and efficient information communication tools which would build confidence among the rural women to take agriculture and allied related decisions and it will also make extension programme more efficient by providing requisite information in user friendly, easy to access at the right time and therefore changing agri-rural environment.

\section{References}

Agnes Godfrey Mwakaje, (2010), Information and communication technology for rural farmers market access in Tanzania. Journal of Information Technology, 10(2): 111-128.

Dhaka BL, Chayal K. (2010). Farmers' Experience with ICTs on transfer of technology in changing agri-rural 
environment. Ind Res J Extension Edu 10(3): 114-118.

Kathlee Freeman. (2017), "ICT use by smallholder farmers in rural Mozambique: A case study of two villages in central Mozambique", Journal of rural social sciences, 32(2), 2017, pp. 1-19.

Kharmudai, A., D. Sumi. Jyothi S.S.P. (2018), "Attitude of Tribal Farmers of Meghalaya towards ICT-Based Extension Services, Indian Journal of Hill Farming, Special issue, pp. 71-75. Raghuprasad, K P., S C Devaraja and Y M
Gopala. (2012), “Attitude of Farmers towards Utilization of Information Communication Technology (ICT) Tools in Farm Communication", Research Journal of Agricultural Sciences, September 2012, 3(5): 10351037.

Shankariah N, Swamy BKN. (2012). Attitude of farmers and scientists towards dissemination of technologies through Mobile Message Service (MMS). Trop Agril Res 24(1): 31 - 41.

\section{How to cite this article:}

Pompy Malakar and Manoshi Baruah Deka. 2020. Attitude of Rural Women of Assam towards ICTs. Int.J.Curr.Microbiol.App.Sci. 9(11): 2198-2201. doi: https://doi.org/10.20546/ijcmas.2020.911.262 